\title{
Pengembangan Perangkat Pembelajaran Fisika dengan Menggunakan Model Pembelajaran Kooperatif Tipe STAD
}

\author{
Muhammad Syahrul Kahar ${ }^{1)}$ \\ 1) Universitas Muhammadiyah Sorong, Kota Sorong, Indonesia \\ E-mail: muhammadsyahrulkahar@gmail.com
}

\begin{abstract}
Abstrak. Penelitian ini adalah penelitian pengembangan yang bertujuan untuk mengembangkan perangkat pembelajaran Fisika dalam pembelajaran Kooperatif tipe STAD di kelas E Prodi Pendidikan Matematika. Subjek penelitian ini adalah mahasiswa kelas E Prodi Pendidikan Matematika sebanyak 35 mahasiswa. Pengembangan pembelajaran Fisika ini terdiri dari empat tahap, yakni tahap pembatasan, tahap rancangan, tahap pengembangan dan tahap penyebaran. Hasil penelitian pengembangan ini menunjukkan bahwa: (1). Untuk tes awal diperoleh skor rata-rata kemampuan penguasaan Fisika mahasiswa 61,85 dari skor ideal 100 dengan standar deviasi 11,05 dan berada pada kategori sedang, (2). Untuk tes akhir diperoleh skor rata-rata 75,57 dari skor ideal 100 dengan standar deviasi 6,94 berada pada kategori tinggi. (3). Terdapat peningkatan penguasaan Fisika mahasiswa dari kategori sedang menjadi kategori tinggi, (4).Tanggapan mahasiswa terhadap perangkat pembelajaran Fisika berupa bahan ajar mahasiswa, lembar kerja mahasiswa, dan rencana pembelajaran cenderung positif, (5). Mahasiswa lebih aktif mengikuti kegiatan pembelajaran
\end{abstract}

Kata Kunci: Perangkat Pembelajaran; Model Pembelajaran Koperatif Tipe STAD; Prestasi Belajar

\section{PENDAhULUAN}

Bidang studi Fisika merupakan bidang studi yang salah satu cirinya bersifat hirarkis, dalam artian setiap konsep harus menurut persyaratan pemahaman atas konsep sebelumnya. Oleh karena itu apabila pada salah satu pokok bahasan terjadi kesulitan maka akan terbawa pada pokok bahasan berikutnya, sehingga pada akhirnya dosen kemungkinan besar akan menjumpai kegagalan dalam mengajarkan atau menjelaskan suatu konsep, dan mahasiswa akan mengalami kesulitan dalam belajar. Untuk itu dosen selalu dituntut dalam pengajaran Fisika agar selalu melakukan usaha-usaha perbaikan proses pengajaran, baik dalam hal materi maupun pengajaran.

Selama ini proses pembelajaran Fisika yang ditemui metodenya konvensional seperti metode ekspositori, demonstrasi, driil, maupun ceramah. Proses ini hanya cenderung mengejar target kurikulum yang dibebankan. Akibatnya patokan yang digunakan bukan penguasaan mahasiswa atas suatu materi tetapi berpatokan pada selesai atau tidaknya suatu materi diajarkan. Dipihak lain mahasiswa yang terbebani menggunakan cara pintas untuk mendapatkan nilai bagus. Salah satunya mencari soal-soal yang pernah dikeluarkan oleh dosen pada tahun sebelumnya dan menghafalkan jawabannya atau meminta les pada dosen yang bersangkutan dengan harapan mendapat latihan seperti soal yang akan di ujikan. Kondisi seperti ini tidak dapat menumbuh kembangkan aspek kemampuan belajar dan aktivitas mahasiswa untuk meningkatkan hasil belajar Fisika, karena mahasiswa tidak aktif dalam belajar, sehingga dalam hal ini mahasiswa mengalami kesulitan dalam belajar Fisika. Belajar membutuhkan peran aktif mahasiswa, yaitu dalam mengkonstruksi dan mengembangkan sumber belajar. Sehingga peran mahasiswa dalam proses belajar bukanlah sebagai suatu objek belajar, melainkan sebagai subjek belajar. Proses aktif mahasiswa sebagai subjek belajar dapat dilakukan dengan interaksi, dan ini merupakan dasar atas munculnya pengetahuan baru.

Sebagian besar atau bahkan semua dosen mengetahui dalam pembelajaran perlu dilakukan penilaian proses di samping penilaian hasil. Namun pada kenyataannya, sebagian dosen ada yang kurang memperdulikan dan tidak melakukan penilaian proses, mereka lebih mementingkan hasil belajar mahasiswa pada akhir semester, akhir tahun, atau ujian akhir. Hal ini terjadi karena sistem penilaian yang terjadi saat ini lebih mengandalkan atau mempercayai hasil akhir dari pada proses belajar mahasiswa. Dengan demikian terjadilah istilah teaching to the test [1], yaitu dosen lebih banyak memberikan cara praktis penyelesaian soal dari pada bersusah payah menerangkan atau membahas teori, walaupun sebenarnya hal itu dapat mengakibatkan mahasiswa tidak mendapatkan pengalaman belajar yang optimal. Dengan pengertian lain, dosen mengajar dan mahasiswa belajar semata-mata untuk ujian saja.

Untuk meningkatkan hasil belajar Fisika maka pemilihan pengajaran yang tepat dapat membantu pengajaran dalam 
kelas, salah satunya dengan menggunakan pembelajaran kooperatif tipe STAD (Student Teams Achievement Division). Pembelajaran kooperatif ini mencakupi suatu kelompok kecil mahasiswa yang bekerja sebagai sebuah tim untuk menyelesaikan suatu masalah, menyelesaikan suatu tugas atau mengerjakan sesuatu untuk mencapai tujuan bersama lainnya. Pembelajaran ini menekankan pada aspek sosial antar mahasiswa dalam kelompok yang heterogen.

Pembelajaran kooperatif ini memanfaatkan kecenderungan mahasiswa untuk lebih berinteraksi dalam belajar sehingga tujuan pembelajaran dapat tercapai dan hasil belajar dapat ditingkatkan. Berdasarkan latar belakang di atas, maka masalah dalam penelitian ini adalah bagaimana mengembangkan perangkat pembelajaran pada pokok bahasan Fluida berdasarkan pembelajaran kooperatif. Perangkat pembelajaran yang dimaksud adalah Bahan ajar Mahasiswa, Lembar Kegiatan mahasiswa (LKM), dan Satuan Acara Perkuliahan (SAP). [2] menjelaskan bahwa STAD (Student Teams Achievement Divisions) merupakan salah satu pendekatan dalam pembelajaran kooperatif yang paling sederhana, yang dikembangkan oleh Robert Slavin di Universitas John Hopkin. Dalam suatu penelitian yang lain oleh [3] menyatakan bahwa adanya pengaruh positif bagi mahasiswa penggunaan strategi model pembelajaran kooperatif Student Team Achievement Division (STAD) terhadap hasil pembelajaran di samping kemampuan yang dimiliki mahasiswa. Strategi pembelajaran kooperatif memasuki jalur utama praktik pendidikan karena dapat meningkatkan pencapaian prestasi akademik mahasiswa dan dapat mengembangkan hubungan antar kelompok serta tumbuhnya kesadaran mahasiswa bahwa mahasiswa perlu belajar untuk berpikir dalam menyelesaikan masalah bersama [4].

Oleh karena beberapa permasalahan diatas sehingga perlu adanya suatu pengembangan perangkat pembelajaran dalam pembelajaran koperatif tipe STAD sehingga peningkatan hasil belajar mahasiswa dapat menjadi lebih baik.

\section{METODE}

\section{A. Jenis Penelitian}

Jenis penelitian ini adalah penelitian pengembangan meliputi pengembangan perangkat pembelajaran, yang terdiri dari (1) Bahan Ajar mahasiswa, (2) Lembar Kerja mahasiswa, dan (3) Satuan Acara Perkuliahan.

\section{B. Lokasi dan Subjek Penelitian}

Penelitian ini dilaksanakan Pada mahasiswa Prodi Pendidikan Matematika UM-Sorong. Dan subjek penelitiannya adalah mahasiswa kelas E semester genap tahun akademik 2016/2017, dengan jumlah mahasiswanya 35 orang.

\section{Pengembangan Perangkat Pembelajaran Fisika}

Pengembangan perangkat pembelajaran Fisika yang digunakan mengacu pada model 4-D Thiagarajan. Model ini merupakan sistem pendekatan pengembangan pembelajaran yang dilakukan meliputi 4 tahap, yaitu pembatasan, rancangan, pengembangan dan penyebaran. Pada tahap penyebaran belum dapat dilakukan dalam penelitian ini. Berikut adalah uraian secara rinci tahap-tahap pengembangan model 4-D yang digunakan dalam penelitian ini [5].

\section{1) Tahap Pembatasan}

Tujuannya adalah menetapkan dan menentukan syaratsyarat pembelajaran yang meliputi tujuan pembelajaran, dan pembatasan materi pembelajaran. Adapun langkahlangkahnya sebagai berikut.

\section{a) Analisis mahasiswa}

Analisis mahasiswa merupakan telaah tentang karakteristik mahasiswa yang sesuai dengan desain pengembangan perangkat pembelajaran. Karakteristik itu meliputi latar belakang kemampuan akademik (pengetahuan) dan perkembangan kognitif.

\section{b) Analisis konsep}

Analisis konsep digunakan untuk mengidentifikasi konsepkonsep utama yang akan diajarkan kemudian disusun secara sistematis konsep-konsep yang relevan.

\section{c) Analisis tugas}

Analisis tugas ini meliputi analisis terhadap tugas-tugas yang dilakukan oleh mahamahasiswa selama pembelajaran berlangsung. Tujuannya adalah untuk memudahkan dosen merumuskan tujuan pembelajaran khusus (indikator pencapaian hasil belajar) yang ingin dicapai.

\section{d) Spesifikasi tujuan pembelajaran}

Tujuannya adalah untuk mengkonversi tujuan analisis konsep dan tugas menjadi tujuan-tujuan pembelajaran khusus, yang dinyatakan dengan tingkah laku. Selanjutnya tujuan pembelajaran khusus tersebut dijadikan dasar untuk menyusun tes dan merancang perangkat pembelajaran.

\section{2) Tahap Rancangan}

Tujuannya adalah untuk menghasilkan prototipe bahan pembelajaran yang dikembangkan, mencakup penyusunan tes dan pengembangan bahan pembelajaran. Langkah-langkahnya adalah sebagi berikut:

\section{a) Penyusunan tes}

Berdasarkan analisis konsep dan analisis tugas, maka dapat disusun suatu tes yang akan menjadi instrumen pengumpul data tentang tingkat penguasaan mahamahasiswa terhadap materi yang akan diajarkan.

\section{b) Pemilihan media}

Pemilihan media dalam penelitian ini disesuaikan dengan hasil analisis tugas, analisis konsep, karakteristik mahamahasiswa, dan fasilitas yang ada di kampus.

\section{c) Pemilihan format}

Pemilihan format dalam pengembangan perangkat pembelajaran ini meliputi pemilihan format untuk merancang isi materi, pemilihan strategi pembelajaran, dan sumber belajar. 


\section{JIP Fo}

d) Rancangan awal

Rancangan awal yang dimaksud adalah rancangan seluruh kegiatan yang harus dikerjakan sebelum ujicoba dilaksanakan.

Adapun rancangan awal perangkat pembelajaran tersebut antara lain :

1. Bahan ajar mahasiswa

2. Lembar Kegiatan. mahasiswa (LKM), penguatan, dan pembelajaran ulang.

3. Satuan acara perkuliahan (SAP).

Semua perangkat pembelajaran yang dihasilkan pada tahap ini disebut dengan perangkat pembelajaran draft 1 .

\section{3) Tahap Pengembangan}

Tujuan tahap pengembangan ini adalah untuk menghasilkan bentuk akhir perangkat pembelajaran setelah melalui revisi berdasarkan masukan para pakar ahli dan data hasil ujicoba. Langkah yang harus dilakukan pada tahap ini adalah sebagai berikut:

\section{a) Penafsiran ahli}

Langkah penafsiran ahli antara lain adalah validitas isi. Hal ini berarti validator menelaah semua perangkat pembelajaran yang telah dihasilkan (draft 1). Selanjutnya saran-saran dari para validator digunakan sebagai bahan pertimbangan dan landasan untuk melakukan revisi. Setelah perangkat draft 1 dilakukan perbaikan (revisi 1) maka diperoleh perangkat pembelajaran draft 2 .

b) Uji coba

Sebelum dilakukan ujicoba terbatas dilapangan, perangkat pembelajaran draft 2 disimulasikan terlebih dahulu oleh penulis. Sebagai contoh diambil salah satu SAP untuk disimulasikan. Selanjutnya saran dan kritik dari penelaah, Rekan sejawat, pengamat sebagai bahan pertimbangan dan dasar untuk melakukan perbaikan (revisi 2) terhadap perangkat pembelajaran draft 2 . Hasil perbaikan ini adalah perangkat pembelajaran draft 3 yang siap digunakan untuk uji coba selanjutnya.

Selanjutnya ujicoba dilakukan hanya terbatas pada satu kelas. Tujuan ujicoba adalah untuk mendapatkan masukan dari mahasiswa dan dosen dilapangan dalam rangka untuk merevisi perangkat draft 3 . Kegiatan pembelajaran pada langkah ujicoba ini dilakukan oleh penulis sendiri sebagai dosennya. Rangkaian kegiatan ujicoba ada 3 tahap, yaitu tes awal, pelaksanaan proses pembelajaran, dan tes akhir. Setelah ujicoba selesai, maka selanjutnya memperbaiki (revisi 3) perangkat pembelajaran draft 3 berdasarkan data hasil ujicoba. Akhirnya hasil akhir langkah ini adalah diperoleh perangkat pembelajaran draft 4.

\section{4) Tahap Penyebaran}

Pada penelitian ini tahap penyebaran tidak dilaksanakan, hal ini karena pelaksanaannya hanya ujicoba terbatas saja.

\section{Pengembangan Instrumen}

Untuk memperoleh informasi tentang aktivitas mahasiswa dan dosen selama kegiatan pembelajaran Fisika, keterampilan mahasiswa, respon mahasiswa terhadap pembelajaran Fisika dan pengelolaan dosen dalam kegiatan belajar mengajar, maka perlu mengembangkan instrumen. Instrumen-instrumen itu adalah sebagai berikut.

\section{1) Tes Penguasaan mahasiswa terhadap materi pelajaran}

Tingkat penguasaan mahasiswa terhadap materi pelajaran diperoleh dengan melalui tes yang disusun dan dikembangkan sendiri oleh penulis berdasarkan tujuan pembelajaran yang telah ditetapkan. Tes ini termasuk tes mengukur aspek kognitif mahasiswa berupa bentuk uraian. Selanjutnya setelah perangkat tes diujicobakan kepada sejumlah mahasiswa, maka secara tidak langsung data hasil ujicoba juga digunakan sebagai pertimbangan untuk meperbaiki bahan ajar mahasiswa dan LKM.

Pemberian skor pada hasil tes ini menggunakan skala bebas tergantung dari bobot butir soal tersebut. Jadi dalam pemberian skor total setiap butir tergantung dari banyaknya langkah-langkah penyelesaian dari soal tersebut. Kriteria yang digunakan untuk menentukan skor adalah skala lima berdasarkan teknik kategorisasi standar yang ditetapkan oleh Departemen Pendidikan dan Kebudayaan [11] yaitu:

1. Kemampuan $85 \%-100 \%$ atau skor $85-100$ dikategorikan sangat tinggi

2. Kemampuan $65 \%-84 \%$ atau skor $65-84$ dikategorikan tinggi

3. Kemampuan $55 \%-64 \%$ atau skor $55-64$ dikategorikan sedang

4. Kemampuan $35 \%-54 \%$ atau skor $35-54$ dikategorikan rendah

5. Kemampuan $0 \%-34 \%$ atau skor $0-34$ dikategorikan sangat rendah

Langkah selanjutnya setelah perangkat tes disusun adalah melakukan analisis butir soal baik secara kualitatif maupun kuantitatif. Analisis butir soal secara kualitatif bertujuan untuk melihat butir soal dari segi materi, konstruksi, dan bahasa. Analisis ini sebelum perangkat tes diujicobakan. Sedangkan analisis butir soal dilakukan setelah perangkat tes diujicobakan kepada mahasiswa.

\section{2) Lembar Pengamatan Aktivitas Mahasiswa dan Dosen Selama Pembelajaran.}

Data aktivitas mahasiswa dan dosen selama kegiatan pembelajaran diperoleh dengan melalui observasi di kelas. Alat yang digunakan adalah lembar pengamatan aktivitas mahasiswa dan dosen selama kegiatan pembelajaran. Aktivitas dosen meliputi menyampaikan pendahuluan, memberikan informasi / menjelaskan tentang materi, mengamati kegiatan mahasiswa, memberikan petunjuk / membimbing kegiatan, memotivasi mahasiswa, mengajukan pertanyaan. Aktivitas mahasiswa meliputi mendengarkan / memperhatikan penjelasan dosen atau mahasiswa, membaca (bahan ajar mahasiswa dan LKM), mengerjakan soal latihan, 


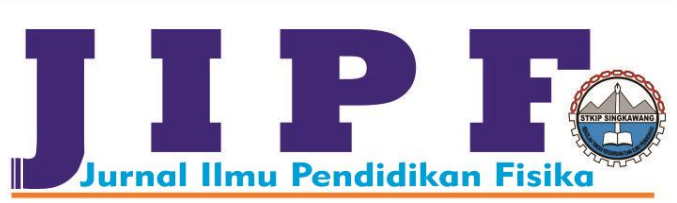

diskusi dengan teman dan dosen, diskusi dengan teman, dan perilaku yang tidak relevan.

\section{3) Respon Mahasiswa Terhadap Kegiatan Pembelajaran}

Data respon mahasiswa terhadap kegiatan pembelajaran Fisika diperoleh melalui angket. Angket tersebut disi oleh mahasiswa setelah mengikuti pembelajaran, dan selanjutnya data ini digunakan sebagai bahan pertimbangan untuk memperbaiki perangkat yang dikembangkan. Respon mahasiswa yang ditanyakan meliputi pendapat maupun komentar mahasiswa terhadap materi pelajaran, kegiatan pembelajaran, dan perangkat pembelajaran.

\section{4) Lembar Pengamatan Pengelolaan Pembelajaran Fisika}

Data pengelolaan pembelajaran Fisika ini meliputi data kemampuan dosen dalam mengelola pembelajaran. Data ini diperoleh melalui pengamatan dengan mengisi lembar pengamatan pengelolaan pembelajaran Fisika. Tujuan dari pengamatan ini adalah untuk mengamati keterampilan dosen dalam menerapkan skenario pembelajaran Fisika yang dijabarkan dalam SAP dan juga sebagai bahan pertimbangan untuk memperbaiki SAP. Indikator pengelolaan pembelajaran Fisika ini meliputi persiapan, pelaksanaan (pendahuluan, kegiatan inti, penutup), pengelolaan waktu, teknik bertanya, dan suasana kelas (berpusat pada mahasiswa, mahasiswa antusias, dosen antusias).

5) Pedoman Pengkategorian Lembar Pengamatan Aktivitas Mahasiswa dan Dosen Untuk Mengkategorikan Lembar Pengamatan Aktivitas Mahasiswa dan Dosen dalam Pembelajaran Fisika, Digunakan Skala Likert.

Berdasarkan uraian di atas, diperoleh kategorisasi sebagai kriteria untuk pengamatan aktivitas mahamahasiswa dan dosen sebagai berikut :

$$
\begin{aligned}
& 0-0,5=\text { Sangat Kurang } \\
& 0,5-1,5=\text { Kurang Baik } \\
& 1,5-2,5=\text { Cukup Baik } \\
& 2,5-3,5=\text { Baik } \\
& 3,5-4=\text { Sangat Baik }
\end{aligned}
$$

\section{HASIL DAN PEMBAHASAN}

\section{A. Pengembangan Perangkat Pembelajaran Fisika}

\section{1) Tahap Pembatasan}

\section{a) Analisis Mahasiswa}

Pada Analisis mahasiswa tentang karakteristik mahasiswa yang diberikan sesuai dengan karakteristik yang meliputi latarbelakang kemampuan akademik mahasiswa dan perkembangan kognitif mahasiswa. Pengetahuan yang harus di kuasai mahasiswa untuk mempelajari pokok bahasan Fluida adalah pengetahuan tentang Fluida statik dan fluida dinamis. Terkait tingkat perkembangan kognitif mahasiswa kelas E sudah mampu mengelompokkan fenomena-fenomena yang ada di sekitarnya.

\section{b) Analisis Konsep}

Konsep utama yang diidentifikasikan pada pengembangan perangkat pembelajaran ini adalah analisis konsep untuk pokok bahasan Fluida.

\section{c) Analisis Tugas}

Analisis tugas berdasarkan pokok bahasan himpunan diperoleh beberapa tugas - tugas yang mengarahkan kemampuan mahasiswa untuk menjawab tugas-tugas sehingga tujuan pembelajaran dapat tercapai.

\section{d) Spesifikasi Tujuan Pembelajaran}

Dilihat dari analisi konsep dan tugas diperoleh indikator pencapaian hasil belajar yang dinyatakan sebagai berikut; Menyatakan masalah sehari-hari; Menyatakan objek yang dapat didefenisikan dengan jelas; Menggambarkan keterkaitan suatu objek.

\section{2) Tahap Rancangan}

\section{a) Penyusunan tes}

Dari hasil analisis konsep dan analisis tugas disusun instrumen tentang tes kemampuan mahasiswa terhadap pokok bahasan Fluida.

\section{b) Pemilihan media}

Pemilihan media disesuaikan dengan hasil analisis tugas, analisis konsep, karakteristik mahasiswa, dan fasilitas di sekolah maka media yang digunakan adalah kumpulan bendabenda yang ada di sekitar mahasiswa atau tempat-tempat lain yang dikenal mahasiswa.

\section{c) Pemilihan format}

Pemilihan format dalam pengembangan perangkat pembelajaran ini meliputi: isi materi adalah pokok bahasan Fluida, model pembelajaran kooperatif dan media pembelajaran bahan ajar mahasiswa dan lembar kegiatan mahasiswa

\section{d) Rancangan awal}

Rancangan awal perangkat pembelajaran tersebut antara lain sebagai berikut:

1. Bahan ajar mahasiswa

2. Lembar Kegiatan Mahasiswa

3. Satuan Acara Perkuliahan

Ketiga perangkat pembelajaran di atas disebut sebagai perangkat draf I.

\section{3) Tahap Pengembangan}

\section{a) Penilaian Ahli}

Pada tahap pengembangan terdiri dari dua langkah yaitu penilaian ahli dan ujicoba. Penilaian ahli berarti validator menelaah semua perangkat pembelajaran yang telah dihasilkan (draf 1). Pada penilaian ahli revisi yang dilakukan terhadap perangkat pembelajaran yang dihasilkan terjadi berulang-ulang kali. Dimulai dari Satuan acara perkuliahan yang belum dilengkapi dengan alokasi waktu pada setiap fase, 


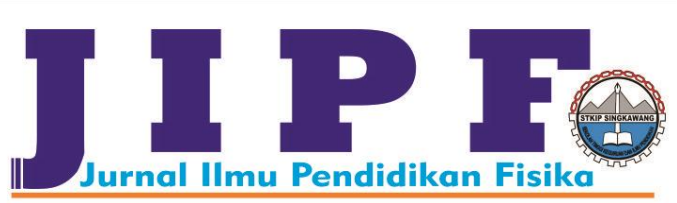

tujuan instruksional, sarana dan media pembelajaran tetapi secara umum penilaian ahli tentang satuan acara perkuliahan ini adalah dapat digunakan dengan revisi kecil dengan skala penilian baik. Pada bahan ajar mahasiswa tentang materi fluida belum begitu jelas, tetapi secara umum penilaian ahli adalah baik dan dapat digunakan dengan revisi kecil. Begitu juga penilaian ahli tentang Lembar Kegiatan Mahasiswa, dapat digunakan dengan revisi kecil dengan skala penilaian baik, walaupun pada Lembar Kerja Mahasiswa belum tercantum alokasi waktu.

b) Uji Coba

\section{Tes Awal}

Sebagaimana analisis deskriptif, maka statistik penguasaan materi sebelum diterapkan pembelajaran kooperatif tipe STAD dilihat dari hasil tes awal mahasiswa kelas E Pendidikan Matematika dapat dilihat pada Tabel 1 berikut ini

TABEL I

Statistik Skor Prestasi Belajar Fisika Mahasiswa Pada Tes Awal

\begin{tabular}{cc}
\hline Variabel & Nilai Statistik \\
\hline Subjek penelitian & 35 \\
Skor Ideal & 100,00 \\
Rata-rata & 61,85 \\
Standar Deviasi & 11,05 \\
Varians & 122,18 \\
Rentang Skor & 40 \\
Skor Maksimum & 75,00 \\
Skor Minimum & 35,00 \\
\hline
\end{tabular}

Skor rata-rata tes awal mahasiswa kelas E Pendidikan Matematika terhadap matakuliah Fisika sebelum diterapkan pembelajaran Kooperatif adalah 61,85 dengan standar deviasi 11,05 dari skor ideal 100. Ini menunjukkan bahwa mahasiswa kelas E Pendidikan Matematika hanya memiliki prestasi belajar rata-rata 62,88. Skor rata-rata tersebut tergolong sedang. Sedangkan secara individual, skor yang dicapai mahasiswa tersebar dari skor minimum 35,00 dan skor maksimum 75,00 dengan rentang skor 40,00. Jika skor tes awal dilihat dari histogram, seperti pada Gambar 1 berikut.

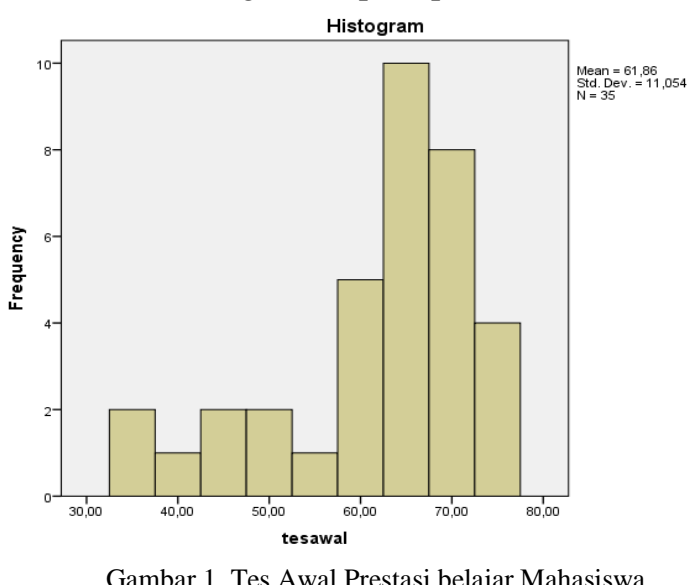

Gambar 1 menunjukkan bahwa skor tes awal mahasiswa untuk rentang 30-50 dengan rata-rata mahasiswa yang
Jurnal Ilmu Pendidikan Fisika

Volume 2 Number 2 month September 2017. Page 42-49 p-ISSN: 2477-5959 e-ISSN: 2477-8451

memperoleh skor tersebut 0-2 mahasiswa, sedangkan untuk skor 60-80 dengan rata-rata mahasiswa yang memperoleh skor tersebut 4-10 mahasiswa, namun dalam rentang skor 60-80 tidak ada mahasiswa yang memperoleh skor tertinggi 80 , hal ini menunjukkan bahwa prestasi mahasiswa masih berada pada kategori sedang dan masih diperlukan beberapa perbaikan untuk peningkatan prestasi belajar yang lebih baik lagi, hal ini sesuai dengan penelitian [6], yang menyatakan bahwa penggunaan sebuah perangkat pembelajaran dengan menggunakan model pembelajaran koperatif sangat efektif dalam pembelajaran.

\section{Tes Akhir}

Hasil analisis deskriptif secara kuantitatif penguasaan Fisika setelah diberi tindakan pada tes akhir dapat dilihat pada Tabel 2. Skor rata-rata tes akhir mahasiswa kelas E Pendidikan Matematika terhadap matakuliah Fisika.setelah penerapan pembelajaran Kooperatif adalah 75,57 dengan standar deviasi 6,94 dari skor ideal $100 \mathrm{Hal}$ ini menunjukkan bahwa mahasiswa kelas E Pendidikan Matematika memiliki prestasi belajar yang jauh lebih baik dengan rata-rata 75,57. Skor rata-rata tersebut tergolong baik. Sedangkan secara individual, skor yang dicapai mahasiswa tersebar dari skor minimum 65,00 dan skor maksimum 90,00 dengan rentang skor 25,00. Jika skor tes awal dilihat dari histogram, seperti pada Gambar 2 berikut.Berdasarkan Gambar 2 menunjukkan bahwa tidak terdapat mahasiswa yang berada di rentang skor $30-60$, sedangkan untuk skor $\geq 65$ dengan rata-rata mahasiswa yang memperoleh skor tersebut 2-12 mahasiswa, namun dalam rentang skor tersebut dominan mahasiswa yang memperoleh skor tertinggi 80 dan juga beberapa mahasiswa yang memperoleh skor 90, hal ini menunjukkan bahwa prestasi mahasiswa telah mengalami perbaikan dengan penerapan perangkat pembelajaran fisika dalam pembelajaran koperatif tipe STAD, hal ini sejalan dengan penelitian Sumarni dan Wustqa serta Jarwadi [6],[7] yang menjelaskan bahwa pengembangan sebuah perangkat pembelajaran dengan dengan model pembelajaran koperatif tipe STAD efektif, praktis dalam meningkatkan hasil belajar. Intan dkk dan Susanto dkk [8],[9] menyatakan bahwa pengembangan sebuah perangkat pembelajaran dengan model koperatif tipe STAD mampu menunjukkan prestasi yang lebih baik, hal ini ditunjukkan dengan skor penilaian yang didapatkan oleh mahasiswa semakin meningkat disetiap pembelajaran dikelas

TABEL II

Statistik Skor Prestasi Belajar FisiKa Mahasiswa Pada Tes AKHIR

\begin{tabular}{cc}
\hline Variabel & Nilai Statistik \\
\hline Subjek Penelitian & 35 \\
Skor Ideal & 100,00 \\
Rata-rata & 75,57 \\
Standar Deviasi & 6,94 \\
Varians & 48,19 \\
Rentang Skor & 25 \\
Skor Maksimum & 90 \\
Skor Minimum & 65 \\
\hline
\end{tabular}





Gambar 2. Tes Akhir Prestasi Belajar Mahasiswa

\section{4) Tahap Penyebaran}

Tahap penyebaran tidak dapat dilaksanakan oleh peneliti karena keterbatasan biaya dan waktu peneliti.

\section{B. Pengembangan Instrumen}

\section{1) Aktivitas Mahasiswa Selama Kegiatan Pembelajaran}

Berdasarkan hasil pengamatan, aktivitas mahasiswa dapat dilihat pada Tabel 3.

TABEL III

Pengamatan AKTIVITAs Mahasiswa

\begin{tabular}{cllllll}
\hline No. & Indikator Pengamatan & \multicolumn{5}{c}{ Pertemuan } \\
& $\mathbf{1}$ & $\mathbf{2}$ & $\mathbf{3}$ & $\mathbf{4}$ & $\mathbf{5}$ \\
\hline 1 & $\begin{array}{l}\text { Mahasiswa menemukan } \\
\text { beberapa cara } \\
\text { menyelesaikan masalah }\end{array}$ & 2 & 3 & 4 & 3 & 4 \\
\hline 2 & $\begin{array}{l}\text { Mahasiswa menemukan } \\
\text { beberapa jawaban masalah }\end{array}$ & 3 & 3 & 4 & 3 & 4 \\
\hline 3 & $\begin{array}{l}\text { Mahasiswa mengemukakan } \\
\text { pikiran }\end{array}$ & 2 & 3 & 3 & 3 & 4 \\
\hline 4 & Mahasiswa berani bertanya & 3 & 3 & 4 & 4 & 4 \\
\hline 5 & $\begin{array}{l}\text { Mahasiswa mengajukan } \\
\text { masalah }\end{array}$ & 2 & 3 & 4 & 3 & 4 \\
\hline 6 & $\begin{array}{l}\text { Mahasiswa menggunakan } \\
\text { model yang mengarah ke } \\
\text { fenomena sekitarnya }\end{array}$ & 2 & 3 & 4 & 3 & 4 \\
\hline
\end{tabular}

Tabel 3 di atas menunjukkan bahwa kecenderungan (dominasi) aktivitas mahasiswa dalam setiap pertemuan yaitu pada indikator pengamatan mahasiswa menemukan beberapa cara menyelesaikan masalah diawal pertemuan cenderung masih kurang tetapi pertemuan-pertemuan berikutnya mengalami peningkatan. Indikator pengamatan yang kedua, mahasiswa menemukan beberapa jawaban masalah diawal pertemuan juga masih kurang. Kedua hal tersebut diatas disebabkan oleh kecenderungan mahasiswa menyelesaikan masalah dengan mengandalkan satu cara pemecahan saja dengan mengikuti cara pemecahan yang diberikan oleh dosen. Pada indikator pengamatan yang ketiga mahasiswa mengemukakan pikiran kecenderungannya juga masih kurang. Seperti halnya pada indikator kelima mahasiswa mengajukan masalah masih pada taraf yang kurang. Akan tetapi pada pertemuan berikutnya mengalami peningkatan terhadap kedua indikator tersebut.

Berbeda dengan indikator pengamatan mahasiswa berani bertanya tidak pada taraf yang kurang, hal ini terlihat dari antusias mahasiswa dengan munculnya berbagai pertanyaan dari mahasiswa. Pada indikator pengamatan ini pada awal pertemuan hingga akhir pertemuan terjadi sedikit peningkatan. Dari beberapa indikator pengamatan di atas secara signifikan menyebabkan indikator pengamatan yang keenam mahasiswa menggunakan model yang mengarah ke notasi formal, diawal pertemuan masih kurang tetapi pada pertemuan berikutnya mengalami peningkatan walaupun masih agak kurang memuaskan.

Hal-hal yang dilakukan mahasiswa dalam penyelesaian masalah dengan membaca bahan ajar mahasiswa dan mengerjakan latihan pada bahan ajar mahasiswa dan lembar kerja mahasiswa. Disamping itu pemberian penjelasan melalui contoh-contoh yang nyata dalam proses pembelajaran membuat mahasiswa lebih tertarik dan aktif belajar. Ini ditunjukkan dengan meningkatnya jumlah mahasiswa yang mengajukan pertanyaan, tanggapan, dan keberanian mahasiswa untuk mengerjakan soal di papan tulis. Hal ini sesuai dengan penelitian Sumarni dan Wustqa serta Jarwadi ([6], [10]), bahwa kegiatan peserta didik dalam pembelajaran berkategori minimal baik dalam pengembangan sebuah perangkat pembelajaran dikelas, baik dengan model pembelajaran apapun.

\section{2) Aktivitas Dosen Selama Kegiatan Pembelajaran}

Sedangkan Tabel 4 pengamatan aktivitas dosen adalah sebagai berikut.

TABEL IV

Pengamatan AKtivitas Dosen

\begin{tabular}{|c|c|c|c|c|c|c|}
\hline \multirow{2}{*}{ No. } & \multirow{2}{*}{ Indikator Pengamatan } & \multicolumn{5}{|c|}{ Pertemuan } \\
\hline & & 1 & 2 & 3 & 4 & 5 \\
\hline 1 & $\begin{array}{l}\text { Dosen memberi cukup } \\
\text { waktu untuk } \\
\text { menyelesaikan masalah }\end{array}$ & 3 & 3 & 3 & 4 & 4 \\
\hline 2 & $\begin{array}{l}\text { Dosen menekankan } \\
\text { pentingnya usaha } \\
\text { mahasiswa untuk } \\
\text { menemukan jawaban } \\
\end{array}$ & 4 & 3 & 4 & 3 & 4 \\
\hline 3 & $\begin{array}{l}\text { Dosen memberikan } \\
\text { arahan yang diperlukan }\end{array}$ & 4 & 3 & 2 & 2 & 4 \\
\hline 4 & $\begin{array}{l}\text { Dosen memberi } \\
\text { perhatian pada } \\
\text { mahasiswa yang } \\
\text { menjawab salah }\end{array}$ & 3 & 3 & 3 & 4 & 3 \\
\hline 5 & $\begin{array}{l}\text { Dosen mendorong para } \\
\text { mahasiswa menanggapi } \\
\text { pemikiran yang } \\
\text { dikemukakan oleh } \\
\text { teman-temannya } \\
\end{array}$ & 3 & 4 & 4 & 3 & 4 \\
\hline 6 & $\begin{array}{l}\text { Dosen menghargai } \\
\text { berbagai pendapat dan } \\
\text { mengendalikan } \\
\text { negosiasi }\end{array}$ & 3 & 4 & 3 & 4 & 4 \\
\hline 7 & $\begin{array}{l}\text { Dosen membagi } \\
\text { mahasiswa menjadi } \\
\text { beberapa kelompok }\end{array}$ & 3 & 3 & 4 & 3 & 3 \\
\hline
\end{tabular}


Tabel 4 menunjukkan bahwa kecenderungan (dominasi) aktivitas dosen pada setiap pertemuan adalah pada indikator pengamatan dosen memberi cukup waktu untuk menyelesaikan masalah menunjukkan kecenderungan yang baik dari setiap pertemuan. Pada indikator pengamatan yang kedua dosen menekankan pentingnya usaha mahasiswa untuk menemukan jawaban diawal pertemuan sudah sangat baik, hal ini bertahan hingga pertemuan selanjutnya. Berbeda dengan indikator yang ketiga dosen hanya memberikan arahan yang diperlukan pada awal pertemuan menunjukkan skor yang baik, tetapi pada pertemuan selanjutnya mengalami penurunan. Sedangkan pada indikator pengamatan dosen memberi perhatian pada mahasiswa yang menjawab salah cenderung meningkat dari setiap pertemuan.

Indikator pengamatan dosen mendorong para mahasiswa menanggapi pemikiran yang dikemukakan oleh temantemannya diawal pertemuan telah menunjukkan skor yang baik hingga pada pertemuan berikutnya terus mengalami peningkatan. Indikator pengamatan yang keenam dosen menghargai berbagai pendapat dan mengendalikan negosiasi menunjukkan skor yang baik bahkan terkadang cukup, hal ini disebabkan dosen terkadang lupa untuk memberikan penghargaan pada mahasiswa. Sedangkan pada Indikator pengamatan yang ketujuh dosen membagi mahasiswa menjadi beberapa kelompok menunjukkan skor yang baik. Hal ini sejalan penelitian Sumarni dan Wustqa serta Jarwadi ([6], [10]), bahwa kegiatan pengamatan untuk tujuh pertemuan terakhir kegiatan mahasiswa berkategori sangat baik. Hasil observasi kegiatan dosen menunjukkan bahwa kegiatan dosen dalam pembelajaran berkategori minimal baik, dan pada pertemuan terakhir kegiatan dosen berkategori sangat baik.

Berdasarkan hal yang disebutkan di atas upaya yang dilakukan dosen yang berupa aktivitas dosen dalam kegiatan pembelajaran yang dimulai dari SAP-1 sampai SAP-14 perlu meningkatkan pemberian arahan terhadap jawaban mahasiswa, agar mahasiswa tidak hanya menemukan satu cara dalam penyelesaian masalah tetapi berbagai cara atau strategi yang digunakan.

\section{3) Respon Mahasiswa Terhadap Kegiatan Pembelajaran}

Pengisian angket tentang respon mahasiswa terhadap kegiatan pembelajaran Fisika sebagai berikut:

1. Sebagian mahasiswa ada yang senang matakuliah Fisika, ada juga yang tidak menyukai Fisika. Menurut mahasiswa matakuliah Fisika itu sulit dan penuh dengan tantangan, terutama dalam mengerjakan soal yang membutuhkan pemahaman dan ketelitian.

2. Ada juga Beberapa mahasiswa yang berpendapat bahwa Fisika itu pelajaran yang penting agar mereka bisa pintar menghitung, karena setiap hari ditemukan dalam kehidupan.

3. Ada juga yang berpendapat bahwa Fisika itu kadangkadang gampang dan kadang-kadang sulit. Ketika mereka mengerti dengan materi maka mereka mengatakan Fisika itu gampang. Begitu juga sebaliknya ketika mereka tidak mengerti maka mereka mengatakan metematika itu sulit sehingga menyebabkan mereka kurang suka dan bosan.

\section{4) Lembar Pengamatan Pengelolaan Pembelajaran Fisika}

Hasil pengamatan Respon dosen terhadap manfaat perangkat pembelajaran Fisika ditunjukkan pada Lembar Observasi Aktivitas Dosen dan mahasiswa dalam Pengembangan Perangkat Pembelajaran Fisika. Pada pertemuan pertama setting kelas masih belum dapat dikendalikan, perlu bimbingan yang lebih lagi dari dosen yang bersangkutan, kemudian Keadaan kelas pada pertemuan pertama berangsur-angsur dapat diatasi dengan adanya kelengkapan atau sarana yang cukup yang dapat menunjang proses belajar mengajar.

Namun perlu diketahui bahwa berdasarkan pengamatan di lapangan ternyata dalam ujicoba ini masih banyak kelemahan. Kelemahan tersebut antara lain, pertama tes penguasaan mahasiswa dalam materi pelajaran. Hal ini karena tes tersebut belum baku sehingga apabila hasil tes mahasiswa tidak baik dapat berarti alat tesnya yang kurang baik atau pembelajarannya yang kurang baik. Kedua, indikator dari aspek yang diamati dalam lembar pengamatan kurang jelas. Hasil penelitian Suyitno [7] menunjukkan bahwa Pengembangan Perangkat Pembelajaran Filsafat melalui Pembelajaran Kooperatif Tipe STAD dengan Strategi Berbasis Kompetensi dan Konservasi dinilai efektif dalam pembelajaran dan respon mahasiswa dalam pembelajaran sangat baik sehingga prestasi belajar mahasiswa juga semakin meningkat.

\section{KESIMPULAN}

Berdasarkan hasil pembahasan ujicoba terhadap mahasiswa kelas E Pendidikan Matematika dengan menggunakan model pembelajaran Fisika kooperatif tipe STAD dapat diambil kesimpulan sebagai berikut:

1. Perangkat pembelajaran Fisika pada pokok bahasan Fluida yang meliputi satuan acara perkuliahan, bahan ajar mahasiswa, lembar kegiatan mahasiswa.

2. Hasil ujicoba perangkat yang dikembangkan dapat diuraikan sebagai berikut:

a. Prestasi belajar mahasiswa pada tes awal dengan rata-rata 61,85 dan pada tes akhir diperoleh rata-rata 75,57 mengalami peningkatan penguasaan Fisika yang tinggi.

b. Aktivitas mahasiswa pada setiap pertemuan cenderung meningkat dengan berdasarkan pada pembelajaran yang didominasi mahasiswa yang aktif.

c. Aktivitas dosen pada setiap pertemuan cenderung tidak terlalu mendominasi pada kegiatan pembelajaran.

d. Respon mahasiswa terhadap kegiatan pembelajaran Kooperatif tipe STAD pada umumnya positif

\section{UCAPAN TERIMAKASIH}

Penulis memberikan penghargaan yg setinggi2nya kepada pimpinan fakultas dan program studi atas dukungan yg diberikan mulai dari proses pengambilan data smpai pada tahap selesainya penelitian ini. 


\section{DAFTAR PUSTAKA}

[1] W. J. Popham, "Teaching to the Test.," Educ. Leadersh., vol. 58, no. 6, pp. 16-20, 2001.

[2] I. Pujiati, "Matematika Melalui Pembelajaran," J. Ilm. Kependidikan, vol. I, no. 1, pp. 1-20, 2008.

[3] F. A. Adesoji and T. L. Ibraheem, "Effects of Student Teams-Achievement Divisions Strategy and Mathematics Knowledge on Learning Outcomes in Chemical Kinetics,” J. Int. Soc. Res., vol. 2, no. 6, pp. 15-25, 2009.

[4] R. Skiba, S. Ritter, A. Simmons, R. Peterson, and C. Miller, "The safe and responsive schools project: A school reform model for implementing best practices in violence prevention," Handbook of school violence and school safety: From research to practice. pp. 631-650, 2006.

[5] Sivasailan and and O. Thiagarajan, "Instructional Development for Training Teachers of Exceptional Children: A Sourcebook.," no. Indiana: Indiana University, p. 194, 1974.

[6] Sumarni and D. U. Wustqa, "Pengembangan Perangkat Pembelajaran pada Materi Pokok Kalkulus SMA Kelas XI Semester 2," J. Ris. Pendidik. Mat., vol. 1, no. 2, pp. 257-267, 2014.

[7] H. Suyitno, "Pengembangan Perangkat Pembelajaran Filsafat Matematika melalui Pembelajaran Kooperatif Tipe STAD dengan Strategi Berbasis Kompetensi dan Konservasi," vol. 6, no. 2, pp. 199-205, 2015.

[8] G. I. Intan Sari Rufiana, \& Mardiyana, "Prodi Magister Pendidikan Matematika, PPs Universitas Sebelas Maret Surakarta," J. Math. Math. Educ., vol. 4, no. 1, pp. 3341, 2014.

[9] H. Susanto, Suyatno, and Madlazim, "Pengembangan Perangkat Pembelajaran Kimia Menggunakan Model Pembelajaran Kooperatif Tipe STAD Berbasis Multiple Representasi untuk Meningkatkan Hasil Belajar Siswa pada Pokok Bahasan Reaksi Reduksi Oksidasi di Kelas X SMA,” Pros. Semin. Nas. Kim., vol. ISBN : 978, no. September, pp. 69-76, 2014.

[10] A. Y. Jarwadi, Sugianto, "Pengembangan Perangkat Pembelajaran Sains Model Student Team Achievement Division (STAD) Berbantuan CD Interaktif Pada Topik Matter and Its State Kelas VII Siswa RSBI Jarwadi 1 ," no. 2003, pp. 59-67, 2009.

[11] Urpiah, (2004). Meingkatkan Kemampuan Penguasaan Fisika Melalui Pendekatan Realistik pada Siswa Kelas V SD Inpres BTN IKIP I Makassar. 